\title{
The gains from trade revisited
}

\author{
Kwok Tong Soo* \\ Department of Economics, Lancaster University Management School, Lancaster LA1 4YX, UK
}

\section{A R T I C L E I N F O}

\section{Article history:}

Received 15 November 2010

Available online 1 December 2010

\section{JEL classification:}

F11

\section{Keywords:}

Gains from trade

Neoclassical trade model

\begin{abstract}
A B S T R A C T
This paper revisits the issue of whether countries gain more from trading with countries that are similar to themselves, or with countries that are different. A model based on relative endowment and technological differences across countries is developed. The main result is that a country may experience a region of increasing gains from trade as its trading partner becomes more similar to itself in terms of relative endowments. The model also predicts that for countries with sufficiently similar relative endowments, both factors of production may experience gains from trade.
\end{abstract}

(c) 2010 Elsevier Inc. All rights reserved.

\section{Introduction}

International trade is an increasingly important part of the global economy. How large are the gains from international trade, and does everyone in a country gain from such trade? This paper addresses both these issues using a simple model of international trade that is based on perfect competition, constant returns to scale, identical homothetic preferences, and differences across countries in terms of relative technology and endowments. The model developed has four goods and two factors of production. This framework, while building on the classical tradition of Ricardo and Heckscher and Ohlin, generates new findings regarding the gains from trade and relative endowment differences across countries.

The first new finding is that, holding relative country sizes constant, the gains from trade may be non-monotonic in relative endowment differences; that is, as countries become more similar to each other in their relative endowments, the gains from trade first decrease, then increase. This non-monotonicity arises because the technological differences may result in a country having a higher factor price for its abundant factor in autarky than its trading partner when relative endowments are not too dissimilar. As relative endowments become more different, the increasing abundance of the abundant factor eliminates this possibility by reducing the autarkic factor price. As a result, the relative difference between countries in factor and goods prices (and hence the gain from trade) is minimised when relative endowments are not identical to each other. This gives rise to what Ethier (2009) has described as "the greater the difference, the greater the gain".

The second new result is that both the abundant and scarce factors of production may gain from trade when relative endowments are not too different between countries, and if countries are sufficiently similar to each other, the scarce factor may gain proportionally more than the abundant factor. However, the scarce factor of production loses from trade if relative endowments are very different between countries. The intuition for this result is similar to that for the first result. The scarce factor loses from trade when the terms of trade work against it, which occurs when countries are very dissimilar to each other. When countries are similar in their relative endowments, this may, as discussed above, give rise to higher relative factor prices for the scarce factor in free trade as compared to autarky. In addition, the scarce factor gains from lower prices as a result of the trading partner's technological superiority. Therefore it is possible that the scarce factor gains from trade when countries are not too dissimilar to each other.

The result that both factors of production can gain from international trade has been obtained in a very different model by Krugman (1981) which assumes identical technologies, increasing returns to scale and monopolistic competition. What this paper

\footnotetext{
* Tel.: +44 1524594418.

E-mail address: k.soo@lancaster.ac.uk.
} 
shows is that this result can be obtained in a constant returns, perfect competition model. However, even in Krugman (1981), the overall gain from trade increases monotonically with differences in relative endowments across countries, so that the first result of overall non-monotonic gains from trade remains novel even when considering models of imperfect competition.

Finally, the paper compares the results of this four-good model to that of the standard two-good model allowing for technological and endowment differences across countries. If a country has a technological superiority in goods which use its abundant factor intensively, then the technological advantage simply reinforces the endowments-based comparative advantage result of the standard Heckscher-Ohlin model. On the other hand, if a country has a technological superiority in goods which use its scarce factor intensively, then a country may in effect be abundant in its scarce factor once the technological difference has been accounted for. This once again results in a non-monotonic gain from trade in relative endowment differences, albeit one which has less subtle effects than in the four-good model.

In the next section we first develop the four-good model, and then discuss the implications of different relative endowments on the gains from trade, both for the country as a whole and for different factors of production. Section 3 outlines the two-good model and compares the gains from trade with those of the four-good model. The final section presents some concluding comments.

\section{The four-good model}

The model is a simplified version of Soo (2009), which is in turn an extension of the Davis (1995) Heckscher-Ohlin-Ricardo model. We impose some strong assumptions on the structure of the model; this means that we cannot draw general conclusions from the analysis, but the simplifications enable us to obtain explicit expressions for the variables of interest, and the model remains rich enough to generate some interesting results. There are two countries, Home $(\mathrm{H})$ and Foreign $(\mathrm{F})$, and two factors of production, skilled (S) and unskilled (U) labour. There are four goods: 1, 2, 3 and 4. Goods 1 and 2 are produced using only skilled labour, while goods 3 and 4 are produced using only unskilled labour. The production functions for the four goods exhibit constant returns to scale and take the following form:

$$
\begin{aligned}
& \text { Home : } Q_{1}^{H}=A S_{1}^{H} \quad Q_{2}^{H}=S_{2}^{H} \quad Q_{3}^{H}=U_{3}^{H} \quad Q_{4}^{H}=U_{4}^{H} \\
& \text { Foreign : } Q_{1}^{F}=S_{1}^{F} \quad Q_{2}^{F}=S_{2}^{F} \quad Q_{3}^{F}=A U_{3}^{F} \quad Q_{4}^{F}=U_{4}^{F}
\end{aligned}
$$

Where $Q_{1}^{H}$ represents the output of good 1 in Home, $A>1$ is the productivity of skilled labour in producing good 1 in Home and unskilled labour in producing good 3 in Foreign. This implies that Home has a technological advantage in producing good 1 and Foreign has a symmetric technological advantage in producing good 3. Perfect competition is assumed. The representative consumer's utility is identical across countries and takes a CES form:

$$
W=\alpha C_{1}^{\theta}+C_{2}^{\theta}+\alpha C_{3}^{\theta}+C_{4}^{\theta} \quad 0<\theta<1
$$

Where $\alpha<1$ represents the weight placed on the technologically differentiated goods relative to the technologically identical goods. In what follows we also assume that the total world endowment of each factor of production is fixed at 4 units, and that the two countries have identical size in terms of their total endowments; that is, $S^{H}+U^{H}=S^{F}+U^{F}=4$. Assume as well that $S^{H}=U^{F} \geq 2$; the two countries are symmetric in terms of their relative endowments, with Home being relatively abundant in

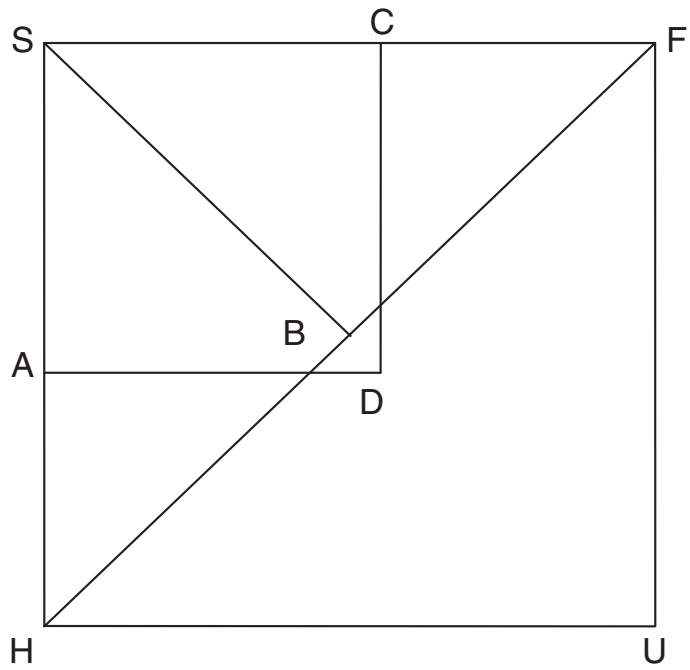

Fig. 1. World Edgeworth Box for the four-good model. 
skilled labour (and Home has a technological advantage in good 1 which uses skilled labour) and Foreign in unskilled labour (and Foreign has a technological advantage in good 3 which uses unskilled labour). ${ }^{1}$ As $S^{H}$ increases, the relative endowments between the two countries become more different from each other.

Fig. 1 shows the world Edgeworth Box which has the world endowment of skilled and unskilled labour on the axes, and the origins for Home and Foreign at opposite corners $\mathrm{H}$ and F. Since the two countries are always identical in size, with the homothetic utility function assumed, point B is the consumption point. The box SACD is the area in which integrated equilibrium can be replicated by free trade and factor price equalisation achieved; this occurs when Home produces the world output of good 1 and Foreign produces the world output of good $3 .^{2}$ The diagonal SB shows the change in the endowment point that occurs as $S^{H}$ changes; as $S^{H}$ increases (and $U^{H}$ falls), the endowment point moves away from B towards $S$, increasing relative endowment differences across countries while preserving relative country sizes.

\subsection{Relative endowments and the gains from trade}

Consider first the case of autarky in Home; we omit the country superscripts in what follows to simplify notation as it does not induce any confusion here. The solution to the consumer's utility maximisation problem is:

$$
C_{1}=\alpha^{\rho} p_{1}^{-\rho} p_{4}^{\rho} C_{4} \quad C_{2}=p_{2}^{-\rho} p_{4}^{\rho} C_{4} \quad C_{3}=\alpha^{\rho} p_{3}^{-\rho} p_{4}^{\rho} C_{4}
$$

where $\rho=\frac{1}{1-\theta}>1$ is the price elasticity of demand for each good, and $p_{1}, p_{2}, p_{3}$ and $p_{4}$ are the prices of each of the four goods. Since under perfect competition profits are zero, and letting the unskilled wage be the numeraire, from the firm's profit maximisation problem we get:

$$
p_{1}=\frac{w_{S}}{A} \quad p_{2}=w_{S} \quad p_{3}=p_{4}=w_{U}=1
$$

where $w_{S}$ is the skilled wage relative to the unskilled wage. National income is:

$$
Y=w_{S} S+w_{U} U=4+\left(w_{S}-1\right) S
$$

substituting from Eqs. (4), (5) and (6) into the representative consumer's utility function (3) gives indirect utility as a function of prices and wages:

$$
V=\left[\alpha^{\rho} p_{1}^{1-\rho}+p_{2}^{1-\rho}+\alpha^{\rho} p_{3}^{1-\rho}+1\right]^{1-\theta}\left[4+\left(w_{S}-1\right) S\right]^{\theta}
$$

From the relationships in Eqs. (4) and (5) and market clearing, we can obtain the skilled wage $w_{S}$ and the prices of goods 1 and 2:

$$
\begin{aligned}
& w_{S}=p_{2}=\left[\left(\frac{4-S}{S}\right)\left(\frac{1+\alpha^{\rho} A^{\rho-1}}{1+\alpha^{\rho}}\right)\right]^{\frac{1}{\rho}} \\
& p_{1}=\frac{1}{A}\left[\left(\frac{4-S}{S}\right)\left(\frac{1+\alpha^{\rho} A^{\rho-1}}{1+\alpha^{\rho}}\right)\right]^{\frac{1}{\rho}}
\end{aligned}
$$

The skilled wage is greater than unity (and the unskilled wage) only if it is sufficiently scarce, having corrected for the technology parameter $A$. Note that $\frac{\partial w_{S}}{\partial S}, \frac{\partial p_{1}}{\partial S}<0$; a larger endowment of skilled workers reduces the relative scarcity of skilled workers, hence reduces the skilled wage relative to the unskilled wage and the price of skill-intensive goods relative to unskill-intensive goods.

Opening up to international trade results in several things. The technological advantage in Home in good 1 means that replication of the integrated equilibrium involves Home being the only producer of good 1, while the technological advantage of Foreign in good 3 means that Foreign becomes the only producer of good 3. World production of goods 2 and 4 are divided between the two countries depending on the relative endowments net of the resources used in producing goods 1 and 3 . This means among other things that Home benefits from the lower price of good 3 that arises because of Foreign's technological advantage.

In free trade, the prices of goods are equalised, and factor prices are equalised by virtue of the replication of the integrated equilibrium. The prices of goods and factors of production and hence the welfare of each country are independent of each country's

\footnotetext{
1 This assumption may be justified through some form of learning-by-doing, in which a country that is abundant in a factor will produce more of the good that uses that factor, and hence benefit from lower production costs in the long run.

${ }^{2}$ In the succeeding subsection we choose parameter values such that the diagonal SB always lies within the integrated equilibrium, so that factor prices are always equalised in free trade.
} 


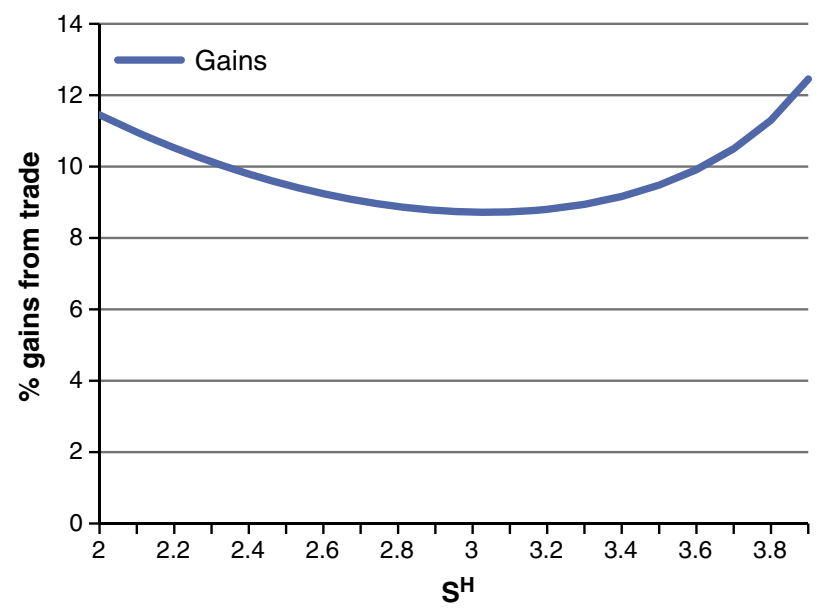

Fig. 2. Gains from trade in the four-good model.

endowment ratio, since they are determined at the world level. Because of the symmetry of endowments, technologies and preferences, free trade prices and wages are the following:

$$
p_{1}=p_{3}=\frac{1}{A} \quad p_{2}=p_{4}=1 \quad w_{S}=w_{U}=1
$$

It is possible to compare the consumer's welfare in autarky and in free trade by substituting the appropriate values of prices and wages from Eqs. (5), (8), (9) and (10) into the indirect utility Eq. (7). For $A=2, S^{H}+U^{H}=S^{F}+U^{F}=4, \theta=0.8$ and $\alpha=0.7$, the representative consumer's percentage gain from trade relative to autarky as a function of $S^{H}$ is shown in Fig. 2. Countries always gain from trade in this model. As $S^{H}$ increases, the two countries become more different in terms of their relative endowments. As this occurs, the gain from trade first decreases, then increases. Therefore, countries that are more similar to each other in their relative endowments can gain more from trade than countries that are less similar to each other. ${ }^{3}$

The intuition for this non-monotonicity is the following. There are two effects of opening up an economy to international trade. First, there is the change in relative prices that results from differences in relative endowments across countries. Second, there is the change in relative prices that results from differences in relative technologies across countries. The second change manifests itself in the lower price for good 3 that Home enjoys under free trade as a result of Foreign's specialising in good 3 in which it has a technological advantage. The first change is more subtle. Fig. 3 shows the skilled wage in Home and Foreign in autarky as a function of $S^{H}$ (Eq. (8)). When $S^{H}$ is relatively close to 2, Home has a higher autarkic skilled wage than Foreign, while the opposite is true when $S^{H}$ is relatively close to 4 . That is, even though Home is relatively abundant with skilled labour compared to Foreign in quantity terms, because of the technological difference between the two countries, Home is skill-scarce relative to Foreign in price terms. When $S^{H}$ is relatively close to 2, Home imports good 2 in free trade because it lacks the skilled labour to produce its demand for good 2 after it has produced the world output of good 1 . Foreign would have a lower autarkic price for good 2 in this case. When $S^{H}$ is relatively close to 4 , Home exports good 2 instead, because now it has enough skilled labour after producing the world output of good 1 to still produce enough of good 2 for export. This means that at some intermediate value of $S^{H}$, neither country exports good 2 , and the autarkic wages are identical in the two countries; this is the point where the two wage curves intersect with each other in Fig. 3.

Suppose that the endowments of the two countries were such that the autarkic wages (of both skilled and unskilled workers) were identical to each other. In this case, opening up to international trade implies that Home gains from the lower prices of good 3 , but not from changes in wages. This is the point where price differences between the two countries are minimised. As a result, from Fig. 2 we see that this is also the point where the gain from trade is minimised. We therefore replicate the result in Ethier (2009) that "the greater the difference, the greater the gains". In this case, this occurs at a point where the countries' relative endowments are not the same as each other.

\subsection{Welfare implications of trade on different factors of production}

It is possible to decompose the gains from trade into the gains from trade for owners of skilled and unskilled labour, and investigate whether international trade leads to gains or losses for each group. The indirect utility of skilled and unskilled workers can be written as:

$$
V_{S}=\left[\alpha^{\rho} p_{1}^{1-\rho}+p_{2}^{1-\rho}+\alpha^{\rho} p_{3}^{1-\rho}+1\right]^{1-\theta}\left[w_{S} S\right]^{\theta}
$$

\footnotetext{
${ }^{3}$ It is also possible to choose parameter values such that the gains from trade increase monotonically as $\mathrm{S}^{\mathrm{H}}$ rises; however, the non-monotonicity holds under many parameter combinations.
} 


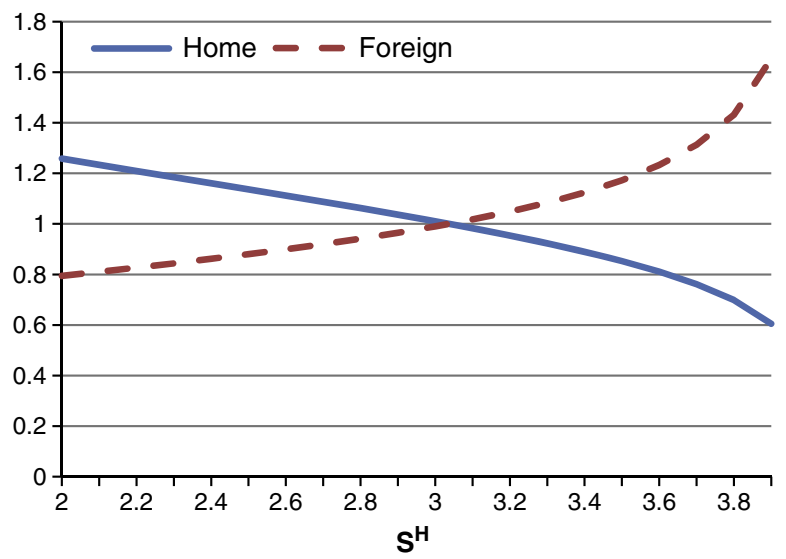

Fig. 3. Autarkic skilled wages in Home and Foreign.

$$
V_{U}=\left[\alpha^{\rho} p_{1}^{1-\rho}+p_{2}^{1-\rho}+\alpha^{\rho} p_{3}^{1-\rho}+1\right]^{1-\theta}[4-S]^{\theta}
$$

Fig. 4 graphs the gains from trade relative to autarky for skilled and unskilled workers in Home as a function of $S^{H}$, for the same parameter values as in Fig. 2. As the two countries become more different in their relative endowments $\left(S^{H}\right.$ rises), the scarce factor's (U) gain from trade decreases, whereas the abundant factor's (S) gain from trade increases. Given our choice of parameter values, when countries are similar in terms of their relative endowments (when $S^{H}$ is close to 2 ), both factors of production gain from trade. As countries become more different from each other (as $S^{H}$ increases), the scarce factor starts to experience losses from trade. These results are similar to those obtained by Krugman (1981) in a very different model. Nevertheless, as Fig. 4 shows, when countries are very similar to each other, the scarce factor experiences proportionally larger gains from trade than does the abundant factor.

From the discussion in the previous subsection, it is clear that when $S^{H}$ is relatively close to 2, Home is in fact skill-scarce in price terms. As a result, the gain from trade to skilled labour is relatively small and arises from a combination of the gain from lower prices of good 3 and the fall in the skilled wage. As $S^{H}$ increases, Home eventually becomes skill-abundant, and therefore skilled labour gains from trade in the form of both higher skilled wages and lower prices for good 3, resulting in an increasing gain. The opposite argument holds for unskilled labour. When $S^{H}$ is relatively close to 2, Home is in fact unskill-abundant in price terms, and therefore unskilled labour gains from trade in the form of both higher (relative) wages and lower prices for good 3 . As $S^{H}$ increases, Home becomes unskill-scarce, and therefore unskilled labour loses from lower relative wages, which is not completely offset by the gain from the lower prices of good 3.
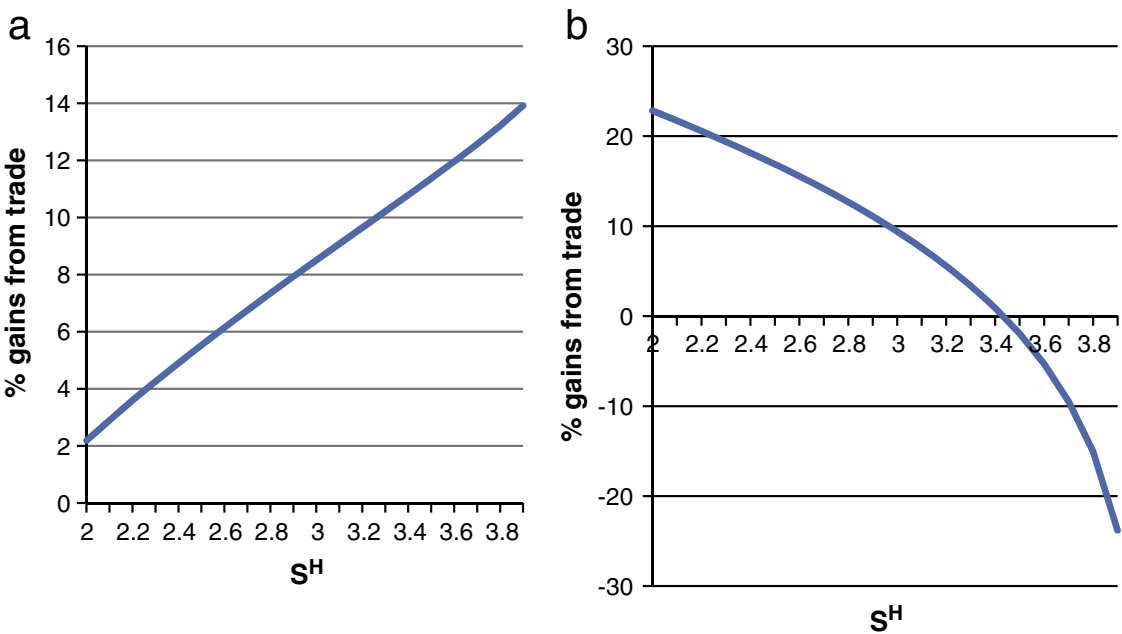

Fig. 4. a: Gains from trade in the four-good model for $\mathrm{S}^{\mathrm{H}}$ (the abundant factor).b: Gains from trade in the four-good model for $\mathrm{U}^{\mathrm{H}}$ (the scarce factor). 


\section{The two-good model with technological differences across countries}

It is useful to compare the results of the four-good model as shown previously with those of a more-standard, two-good, twofactor, two-country model, in which the technology differs across countries. Consider again the simple structure of the model above, in which there are now two goods, 1 and 2, where good 1 is produced using only skilled labour, and good 2 is produced using only unskilled labour. Given the simpler structure of the two-good model, it is possible to consider two cases: First, when countries have a technological advantage in the good which uses their abundant factor, and second, when countries have a technological advantage in the good that uses their scarce factor.

\subsection{Case 1: technological advantage in the good which uses the abundant factor}

Consider first the following technology difference across countries: Home (the skill-abundant country) has a technological advantage in good 1 which uses skilled labour, whereas Foreign (the unskilled-abundant country) has a technological advantage in good 2 which uses unskilled labour. Assume that the two countries' technological advantages are symmetric. The production functions are now:

$$
\begin{aligned}
& \text { Home : } Q_{1}^{H}=A S^{H} \quad Q_{2}^{H}=U^{H} \quad A>1 \\
& \text { Foreign : } Q_{1}^{F}=S^{F} \quad Q_{2}^{F}=A U^{F} \quad A>1
\end{aligned}
$$

Assume (as shown previously) that the two countries are symmetric in their relative endowments, each country has a total of 4 units of labour, and that the total world endowment of each type of labour is also equal to 4 ; that is, $S^{H}=U^{F}>2$, and $U^{H}=S^{F}=4-$ $S^{H}=4-U^{F}<2$. The representative consumer's utility function is now:

$$
W=C_{1}^{\theta}+C_{2}^{\theta} \quad 0<\theta<1
$$

Solving the consumer's optimisation problem gives the following relationship between consumption on each of the two goods:

$$
C_{1}=p_{1}^{-\rho} p_{2}^{\rho} C_{2}
$$

where, as before, $\rho=\frac{1}{1-\theta}$ is the price elasticity of demand for each good.

Consider the case for Home under autarky (we omit the country superscript to simplify notation as it does not induce any confusion here). Let the unskilled wage be the numeraire: $w_{U}=1$; this implies $p_{2}=1$ and $p_{1}=\frac{w_{S}}{A}$. Substituting these and the goods market clearing condition into Eq. (16) enables us to solve for $p_{1}$ and $w_{S}$ :

$$
w_{S}=A\left(\frac{U}{A S}\right)^{\frac{1}{\rho}} \quad p_{1}=\left(\frac{U}{A S}\right)^{\frac{1}{\rho}}
$$

Given our assumptions on endowments and technologies, in Home under autarky, $p_{1}<1$. The greater the technological advantage $A$, the lower the autarkic price of good 1 relative to good 2 . National income is the sum of income to skilled and unskilled workers:

$$
Y=w_{S} S+w_{U} U
$$

The consumer's indirect utility function is therefore:

$$
V=C_{2}^{\theta}\left[1+\left(\frac{p_{1}}{p_{2}}\right)^{1-\rho}\right]=\left[1+\left(\frac{p_{1}}{p_{2}}\right)^{1-\rho}\right]^{1-\theta}\left(\frac{w_{S} S+w_{U} U}{p_{2}}\right)^{\theta}
$$

When the country opens up to free international trade, prices of goods are equalised across countries. Let the wage rate of the factor which is technologically inferior be equal to 1 in each country: $w_{U}^{H}=w_{S}^{F}=1$. This implies that the wage rate of the technologically superior factor is $w_{S}^{H}=w_{U}^{F}=A$, and also that the free trade prices of both goods are equal to $1: p_{1}=p_{2}=1$. Factor price equalisation is not achieved in this model because of the technological differences across countries. The difference in the consumer's indirect utility function in free trade as compared to autarky arises from the differences in prices and wages between the two scenarios.

As with the four-good model above, Fig. 5 graphs the percentage gains from trade relative to autarky as a function of $S^{H}$, for the same parameter values as before. In this case, the results are straightforward. Since Home is abundant in skilled labour and is better technologically in the skill-intensive good, both forces work in the same direction: as $S^{H}$ increases, the two countries become more different from each other and hence the gain from trade increases. 


\section{Gains}

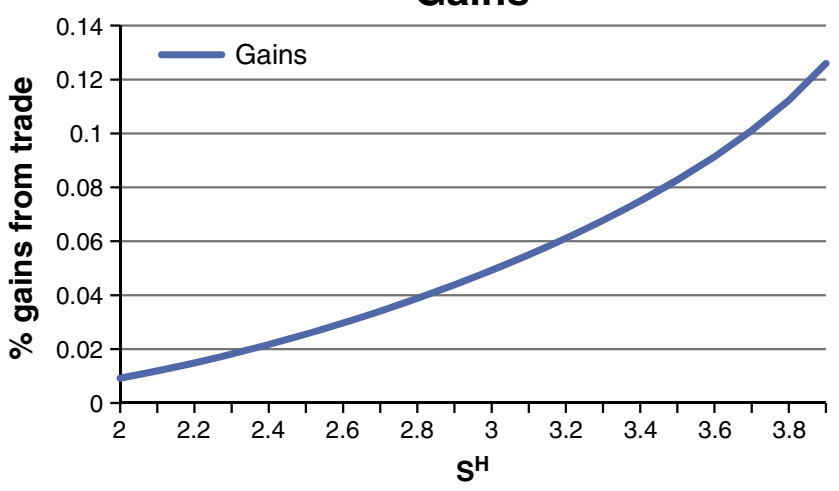

Fig. 5. Gains from trade in the two-good model when each country has a technological advantage in the good which is intensive in its abundant factor (Case 1 ).

As before, the welfare implications of international trade can be divided into the welfare implications for skilled and unskilled workers separately. For skilled workers, the indirect utility function becomes:

$$
V_{S}=\left[1+\left(\frac{p_{1}}{p_{2}}\right)^{1-\rho}\right]^{1-\theta}\left(\frac{w_{S} S}{p_{2}}\right)^{\theta}
$$

Similarly, for unskilled workers, the indirect utility function is:

$$
V_{U}=\left[1+\left(\frac{p_{1}}{p_{2}}\right)^{1-\rho}\right]^{1-\theta}\left(\frac{w_{U} U}{p_{2}}\right)^{\theta}
$$

In this case, the abundant skilled workers always gain from trade, while the scarce unskilled workers always lose from trade. Once again, this is because technology and endowments work in the same direction and so reinforce the results of the standard Heckscher-Ohlin model with identical technologies. This is shown in Fig. 6.

\subsection{Case 2: technological advantage in the good which uses the scarce factor}

This time, consider the situation in which Home is once again the skill-abundant country, but has a technological advantage in the unskill-intensive good, while the unskill-abundant Foreign has a technological advantage in the skill-intensive good $(A>1$ as before):

$$
\text { Home : } Q_{1}^{H}=S^{H} \quad Q_{2}^{H}=A U^{H}
$$
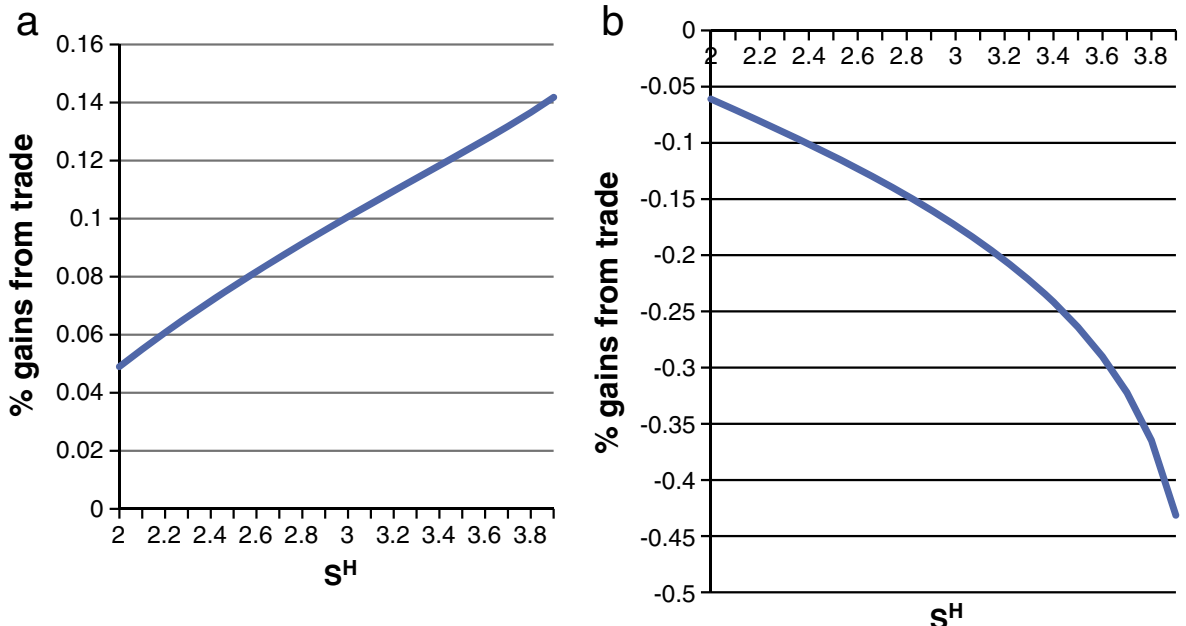

Fig. 6. a: Gains from trade in the two-good model (Case 1) for $\mathrm{S}^{\mathrm{H}}$ (the abundant factor). b: Gains from trade in the two-good model (Case 1 ) for $\mathrm{U}^{\mathrm{H}}$ (the scarce factor). 
Gains

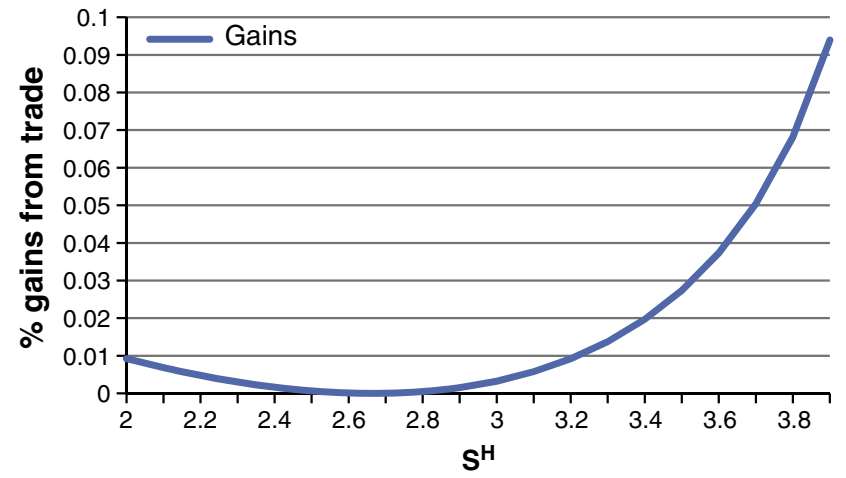

Fig. 7. Gains from trade in the two-good model when each country has a technological advantage in the good which is intensive in its scarce factor (Case 2).

$$
\text { Foreign : } Q_{1}^{F}=A S^{F} \quad Q_{2}^{F}=U^{F}
$$

Endowments and consumer preferences are identical to the previous subsection. Consider the case of Home under autarky, and once again omit the country superscript to simplify notation as it does not induce any confusion. Taking the wage rate of the unskilled worker in Home as the numeraire again, we have $w_{U}=1, p_{2}=\frac{1}{A}$, and from the consumer's optimisation problem:

$$
p_{1}=w_{S}=\frac{1}{A}\left(\frac{A U}{S}\right)^{\frac{1}{\rho}}=A^{-\theta}\left(\frac{U}{S}\right)^{\frac{1}{\rho}}
$$

As shown previously, the larger the technology parameter $A$, the lower is the autarkic price of good 1; but unlike Case 1, the higher its price relative to that of good 2. The consumer's indirect utility function under is identical in form to that in the previous subsection. In free trade, assume again that the unskilled wage in Home is the numeraire: $w_{U}^{H}=w_{S}^{F}=1$; this implies that $w_{S}^{H}=w_{U}^{F}=\frac{1}{A}$, and $p_{1}=p_{2}=\frac{1}{A}$.

Fig. 7 shows the overall gain from trade as a function of $S^{H}$, while Fig. 8 shows the gain from trade for skilled and unskilled workers separately, again for the same parameter values as before. The overall gain from trade first decreases, then increases as $S^{H}$ increases. When $S^{H}$ is close to 2, Home is actually skill-scarce due to Foreign's technological advantage in the skill-intensive good 1 ; as a result, Home's autarkic price of good 1 is higher than in Foreign, Home imports good 1, and Home's skilled labour experiences a loss from international trade. As $S^{H}$ rises, the two countries become more similar in their technology-adjusted endowment levels, until approximately $S^{H}=2.7$, when the two countries are identical in their technology-adjusted endowment levels, autarkic prices and wages are the same across countries, no trade takes place, and hence there are no gains from trade. Beyond this point, Home is
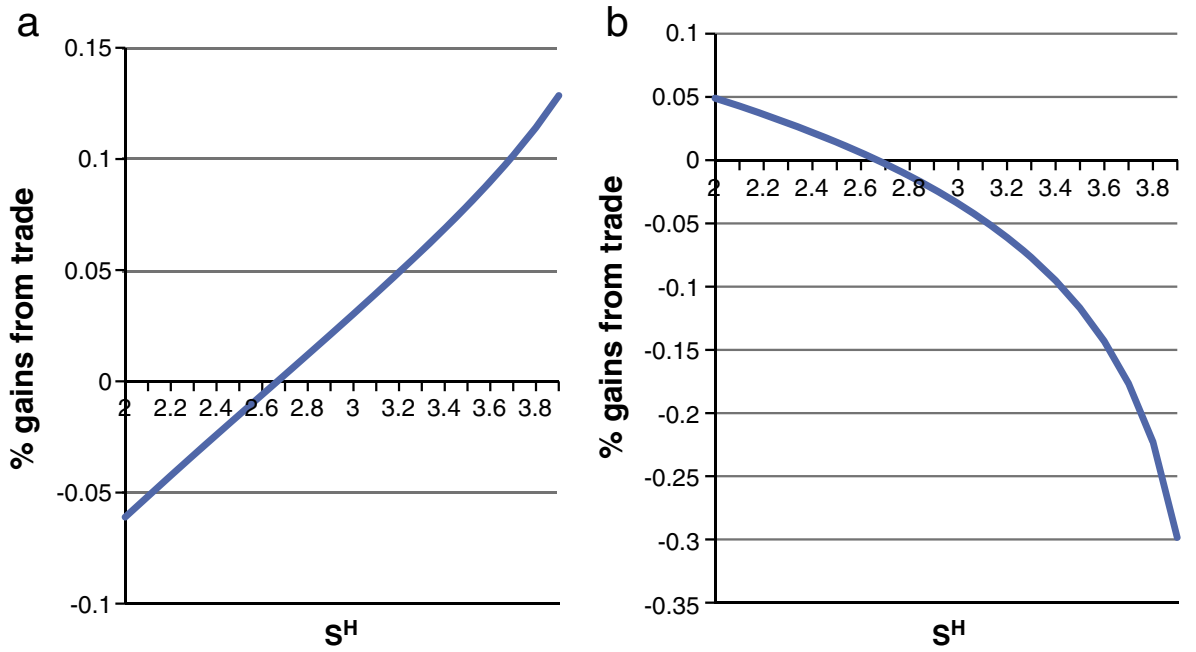

Fig. 8. a: Gains from trade in the two-good model (Case 2) for $\mathrm{S}^{\mathrm{H}}$ (the abundant factor). b: Gains from trade in the two-good model (Case 2) for $\mathrm{U}^{\mathrm{H}}$ (the scarce factor). 
now the skill-abundant country, exports the skill-intensive good, and as a result, skilled labour gains from trade while unskilled labour loses from trade. Therefore, once again the Ethier (2009) result of "the greater the difference, the greater the gains", holds.

This case makes an interesting comparison with the four-good model developed in Section 2. In the four-good model, each country has the technological advantage in one of the two goods which use its abundant factor intensively (as in Case 1 of the twogood model in Section 3.1). However, because there are two goods which are intensive in each factor, when countries are similar in their relative endowments, a country may end up importing the other good which is intensive in its abundant factor, so that the abundant factor actually experiences a decrease in its return in free trade as compared to autarky. This effect is reproduced in Case 2 of the two-good model, because when the two countries are similar in their relative endowments, the country is actually scarce in its abundant factor once the technological difference has been accounted for. However, in the four-good model, the abundant factor remains the abundant factor even after technological differences are accounted for; in fact, its relative abundance increases because the technological difference reinforces the difference in relative abundance. In addition, in the four-good model, the abundant factor always gains from trade, unlike in Case 2 of the two-good model, because the gain from the trading partner's technological advantage always exceeds the possible loss from lower wages. The four-good model also always gives rise to overall gains from the opening up of international trade, whereas there exists endowment levels in Case 2 of the two-good model for which there are no gains from opening up to international trade.

\section{Conclusions}

Recent papers by Ethier (2009) and Kemp and Tran-Nam (2009) have shown the manner in which the gains from trade are related to similarity in relative autarkic prices across countries in comparative advantage models of trade. What the present paper has done is to show how these prices can be related to countries' relative endowment levels, by developing a model that combines elements of the Ricardian model and the Heckscher-Ohlin model of international trade. In doing so, we obtain new results regarding the relationship between the gains from trade and relative endowment differences across countries, and the gains from trade for different factors of production. Although we have imposed some strong assumptions on the model to yield analytical expressions, it is still sufficiently rich to generate some interesting results. The four-good model presented in Section 2 generates gains from trade that may be non-monotonic in differences in relative endowments across countries. It is also able to generate regions where both abundant and scarce factors of production gain from trade, providing an alternative explanation to that commonly found in the literature.

The two-good model presented in Section 3 shows the extent to which the results of the four-good model can be replicated in a simpler model. It turns out that the overall non-monotonic gains from trade result can be replicated in the two-good model only if countries have technological advantages in the good which is intensive in their scarce factor. Nevertheless, there are additional results from the four-good model which cannot be replicated in the two-good model, which adds to the appeal of the more intricate model.

\section{Acknowledgements}

Thanks to Eric Fisher, an anonymous referee, and Dimitra Petropoulou for valuable comments and suggestions which have improved the paper. The author is responsible for any errors and omissions.

\section{References}

Davis, D. R. (1995). Intra-industry trade: a Heckscher-Ohlin-Ricardo approach. Journal of International Economics, 39(3-4), 201 -226.

Ethier, W. J. (2009). The greater the differences, the greater the gain? Trade and Development Review, 2(2), $70-78$.

Kemp, M., \& Tran-Nam, B. (2009). Do trade gains increase with increases in international disparities in factor proportions? In T. Kamihigashi, \& L. Zhao (Eds.), International trade and economic dynamics: Essays in memory of Koji Shimomura. New York: Springer.

Krugman, P. R. (1981). Intraindustry specialization and the gains from trade. Journal of Political Economy, 89(5), 959-974.

Soo, K. T. (2009). Relative endowments and the volume of trade. Journal of Economic Integration, 24(4), 744-764. 